\title{
Molecular Typing of Enterococcus faecalis from Persistent Endodontic Infections
}

\author{
Tipificación Molecular de Enterococcus faecalis Provenientes \\ de Infecciones Endodónticas Persistentes
}

\begin{abstract}
Gabriela Sánchez-Sanhueza1; Catherine Villegas²; Ma Ignacia Ulloa²; Carla Pineda; Gerardo González-Rocha ${ }^{3}$; Mariana Domínguez ${ }^{4}$ \& Helia Bello-Toledo ${ }^{4}$
\end{abstract}

\begin{abstract}
SÁNCHEZ-SANHUEZA, G.; VILLEGAS, C.; ULLOA, M. I.; PINEDA, C.; GONZÁLEZ-ROCHA, G.; DOMÍNGUEZ, M. \& BELLO-TOLEDO, H. Molecular typing of Enterococcus faecalis from persistent endodontic infections. Int. J. Odontostomat., 12(1):113-119, 2018.
\end{abstract}

ABSTRACT: Molecular techniques that provide valuable information about the epidemiology of oral strains. The purpose of this study was to determine the genetic relatedness of 83 Enterococcus faecalis strains isolated from treated root canals. These strains were obtained from patients who were treated for persistent endodontic infections. E. faecalis isolates were molecular typed by Pulsed Field Gel Electrophoresis using Smal. Ten clonal groups and 13 pulse types with $38.7 \%$ similarity for the less related strains were identified. Genetic heterogeneity among strains from different patients and a high level of genetic homogeneity among intrapatient strains were observed. Therefore, restriction endonuclease fingerprinting of genomic DNA from $E$. faecalis strains confirmed the polyclonality of the isolates obtained from the root canals of patients diagnosed with persistent endodontic infections, compared with other reports. These results provide additional data for a better understanding of the epidemiological aspects of root canal infections by $E$. faecalis.

KEY WORDS: Enterococcus faecalis, pulsed field gel electrophoresis, apical periodontitis nonsuppurative.

\section{INTRODUCTION}

A primary goal of endodontic treatment is to eliminate microorganisms that colonize the dental pulp causing their necrosis (Atila-Pektas et al., 2013) with appropriate instrumentation, irrigation and medication (Baca et al., 2011; Hohscheidt et al., 2013). Nevertheless, despite various therapeutic alternatives, the complete eradication of $E$. faecalis has not been possible (Rôças et al., 2004; Kumar, 2013; Javidi et al., 2014). This aerobic facultative Gram-positive bacterium is regarded as the main cause of persistent endodontic infection after root canal treatment, being the gold standard bacteria in endodontic microbiology studies. The microbiota that are associated with root canal treatment failure with periapical chronic periodontitis are different from those in necrotic canals, and it is necessary to characterize their features (Vengerfeldt et al., 2014). Resistance of $E$. faecalis strains has been well documented and has persisted after irrigation with disinfectants, such as sodium hypochlorite (Pladisai et al., 2016). Molecular techniques that provide valuable information about the epidemiology of resistant bacterial strains, such as macrorestriction of genomic DNA and subsequent Pulsed Field Gel Electrophoresis (PFGE), are highly precise and reproducible typing methods for determining genetic relatedness among $E$. faecalis isolates (Castillo-Rojas et al., 2013). That method has been used to characterize isolates obtained from clinical samples (Al-Ahmad et al., 2010; Zhu et al., 2010; Vidana et al., 2011) and to

${ }^{1}$ Assistant Professor. Department of Restorative Dentistry, Faculty of Dentistry, Doctoral Student, Universidad de Concepción, Concepción, Chile.

2 Postgrade Student in Endodontics, Faculty of Dentistry, Universidad de Concepción, Chile.

${ }^{3}$ Professor. Research Laboratory on Antibacterial Agents, Department of Microbiology, Faculty of Biological Sciences, Universidad de Concepción, Concepción, Chile.

${ }^{4}$ Associate Professor. Research Laboratory on Antibacterial Agents, Department of Microbiology, Faculty of Biological Sciences, Universidad de Concepción, Concepción, Chile.

Project VRID UDEC N²14.102.015-1. CONICYT-PCHA/Doctorado Nacional/2013 folio 21130022. 
type isolates obtained from root canals, providing differences in the epidemiological behavior of local strains. But there are few and very poorly detailed studies to reproduce the technique. Recently a study was published about diversity and similarity of Enterococcus faecalis genotype isolates from multiple oral sites using techniques, like repetitive sequencebased polymerase chain reaction and arbitrarily primed polymerase chain reaction (AP-PCR), which emphasizes the importance of typing (Delboni et al., 2017). The aim of this study was to determine the genetic relatedness between the $E$. faecalis isolates from the root canals of patients who were undergoing treatment for persistent endodontic infections using a good description of PFGE, another technique to have information on this important topic.

\section{MATERIAL AND METHOD}

Bacterial Strains. The study was performed in compliance with the protocol approved by the Faculty Ethical Committee (C.I.Y.B number 08/14). Eighty-three $E$. faecalis strains isolated from root canals retreated for a diagnosis of Chronic Nonsuppurative Periapical Periodontitis were included. These strains were isolated from fourteen patients and a random non-correlative number was assigned to each patient. Clinical characteristics, strains isolation methodology and identification, at the species level by molecular methodologies, were previously published (SánchezSanhueza et al., 2015). Strains were stored until to molecular typing at $-80{ }^{\circ} \mathrm{C}$ in a mixture of Trypticase soy broth (Oxoid Ltd., Basingstoke, Hampshire, England) and glycerol (50 \% v/v) in a 2:1 ratio.

Molecular Typing. The genetic relatedness of the $E$. faecalis strains was assessed using PFGE in a CHEFDR II apparatus (Bio-Rad, La Jolla, CA). Salmonella enterica subsp. enterica serotype Braenderup H9812 strain was used as a DNA molecular size control (kindly provided by Instituto de Salud Pública, Chile) and digested with the Xbal (5000 U) restriction enzyme (Roche Molecular Diagnostics, Pleasanton, CA) (Kainer et al., 2007). The Smal (1000 U) restriction enzyme (Roche Molecular Diagnostics, Pleasanton, CA) was used per the Unified Pulsed -Field Gel Electrophoresis (PFGE) Protocol for Gram-Positive Bacteria as described by the Centers for Disease Control and Prevention (2012). E. faecalis strains were grown in Columbia agar plates supplemented with 5 $\%$ bovine blood (BD, Heidelberg, Germany) and incubated at $37^{\circ} \mathrm{C}$ for $24 \mathrm{~h}$ under aerobic conditions. Colonies were inoculated in $3 \mathrm{~mL}$ of the suspension buffer (10 mM Tris; 0.1 mM EDTA; pH 8.0 for E. faecalis and $100 \mathrm{mM}$ Tris; $100 \mathrm{mM}$ EDTA; pH 8.0 for S. Braenderup), and the optical density at $660 \mathrm{~nm}$ was adjusted to 0.9-1.1 for $S$. Braenderup and to 0.6 for $E$. faecalis using an EPOCH spectrophotometer (BioTek $囚$, USA). Subsequently, $400 \mu \mathrm{L}$ of $E$. faecalis suspensions was transferred to a tube containing $20 \mu \mathrm{L}$ of lysozyme (20 mg/mL) (Sigma Aldrich Chemical Co, MO, USA) and incubated for $30-45 \mathrm{~min}$ at $55^{\circ} \mathrm{C}$. Suspensions of $S$. Braenderup were treated with proteinase K $(20 \mathrm{mg} /$ $\mathrm{mL}$ ) (Thermo Scientific, Massachusetts, USA) and incubated at $55{ }^{\circ} \mathrm{C}$ for $10 \mathrm{~min}$. Then, $400 \mu \mathrm{L}$ of $1 \%$ Sea Kem Gold agarose (Lonza, Basilea, Suiza) in buffer TE (10 mM Tris EDTA, pH 8.0) was added to each bacterial suspension, and the suspensions were gently mixed. From each mixture, $300 \mu \mathrm{L}$ were pipetted into plug molds. Agarose plugs were allowed to solidify at room temperature.

For cell lysis, plugs were transferred to Falcon tubes (Kima, Italy) containing $5 \mathrm{~mL}$ of the cell lysis buffer (50 mM Tris; 50 mM EDTA; pH 8.0; $1 \%$ sarcosyl) and $25 \mu \mathrm{L}$ of proteinase $\mathrm{K}(20 \mathrm{mg} / \mathrm{mL})$ and were incubated for $2.5 \mathrm{~h}$ in a $54^{\circ} \mathrm{C}$ shaking water bath, model 1083 (Thermolab®, Burgwedel, Germany) under continuous agitation at $150-175 \mathrm{rpm}$. Afterward, plugs were washed 3 times with $5 \mathrm{~mL}$ of MilliQ water at $54{ }^{\circ} \mathrm{C}$ for 10-15 min with agitation at 150-175 rpm. Three additional washes with $5 \mathrm{~mL}$ of TE buffer were performed, and the plugs were stored in $8 \mathrm{~mL}$ of TE buffer at $4{ }^{\circ} \mathrm{C}$.

One-third of each plug was incubated with 100 $\mu \mathrm{L}$ of Tango buffer (Thermo Scientific, Massachusetts, USA) for $15 \mathrm{~min}$ at $25^{\circ} \mathrm{C}$ for $E$. faecalis and $15 \mathrm{~min}$ at 37 ${ }^{\circ} \mathrm{C}$ for $\mathrm{S}$. Braenderup. The predigestion solution was replaced with $100 \mu \mathrm{L}$ of the digestion solution consisting of $88.5 \mu \mathrm{L}$ of sterile distilled water, $10 \mu \mathrm{l}$ of buffer Tango and $1.5 \mu \mathrm{L}$ of $S m a l$ (10 units $/ \mu \mathrm{L}$ ) for $E$. faecalis and 1.5 $\mu \mathrm{L}$ of Xbal (10 units $/ \mu \mathrm{L}$ ) for $S$. Braenderup. After a $4 \mathrm{~h}$ incubation at the optimum temperature for each enzyme, the digestion solution was removed, and plugs were loaded onto $1 \%$ SeaKem ${ }^{\circledR}$ Gold agarose gels. The remaining plugs were stored up to 7 days in $200 \mu \mathrm{L}$ of $0.5 X$ Tris-borate-EDTA buffer (TBE, Thermo Scientific, Massachusetts, USA) at $4{ }^{\circ} \mathrm{C}$.

PFGE was performed using 0.5X TBE buffer with $760 \mu \mathrm{L}$ of the thiourea stock solution $(10 \mathrm{mg} / \mathrm{mL})$ under the following conditions: $14{ }^{\circ} \mathrm{C}, 6 \mathrm{~V} / \mathrm{cm}, 19 \mathrm{~h}$ run-time, 3.5 to $23.5 \mathrm{~s}$ switch times, and $1 \mathrm{~L} / \mathrm{min}$ flow rate (Ribeiro et al., 2009). The gel was stained with ethidium bromide 
$(0.5 \mu \mathrm{g} / \mathrm{mL})$ for $25 \mathrm{~min}$, washed under agitation with MilliQ water for $20 \mathrm{~min}$ and visualized using a UV transilluminator (UVItec system, Cambridge, UK).

Gel Analyses. An initial visual analysis of the gels (visible to the naked eye) for the 83 strains was carried out per the criteria proposed by Tenover et al. (1995), and a selected group of these strains were used for further analysis using the BioNumerics v.6.611 software (AppliedMaths, Inc., Austin, TX, USA) based on 2 or 3 strains for each distinct pattern. The band positions were normalized using the $S$. Braenderup strain as the standard marker in each gel. The PFGE pattern homology dendrogram was built using the Dice coefficient with a tolerance level of $1.5-2 \%$ and with the UPGMA method, and $85 \%$ similarity was established as the measure for classifying a group as closely related (Werner et al., 2013).

\section{RESULTS}

In 6 patients $(42.8 \%)$, E. faecalis strains with at least two different fingerprints per the Tenover criteria, (Tenover et al.) were detected, including a nongenetically related strain. In $35.7 \%$ of patients, the 6 strains were catalogued as indistinguishable, i.e., clones, and $21.4 \%$ of the patients presented 5 clonal strains and one closely related strain (Fig. 1).
The Smal digestions and PFGE of the DNA from the $E$. faecalis strains yielded 13 different fingerprints that included 14 to 16 bands, with sizes ranging from approximately 15 to $1200 \mathrm{~kb}$ (Fig. 2).

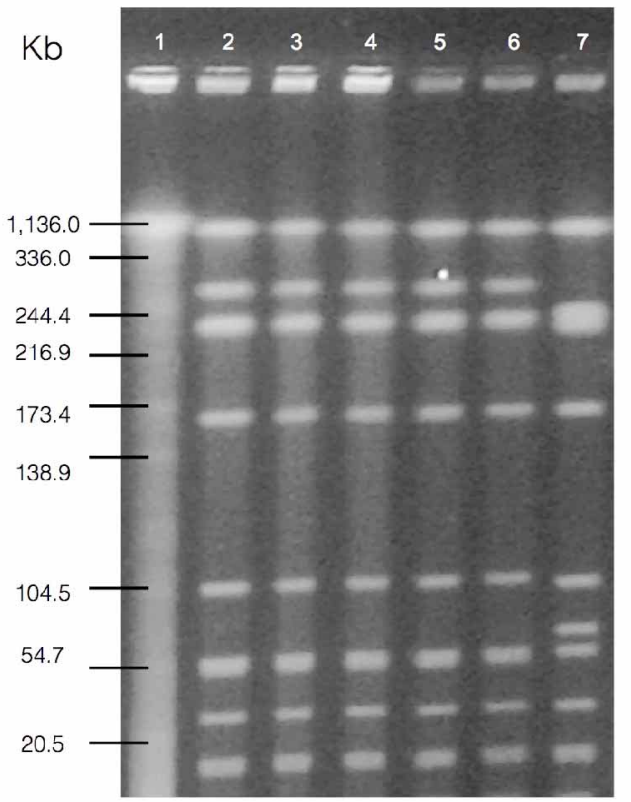

Fig. 2. Representative PFGE fingerprinting of $E$. faecalis strains isolates from a root canal in patient $n^{\circ} 8$ diagnosed with a persistent endodontic infection. Lane 1: Gel size standard strain Salmonella Braenderup. Lanes 2 to 7 : E. faecalis strains.

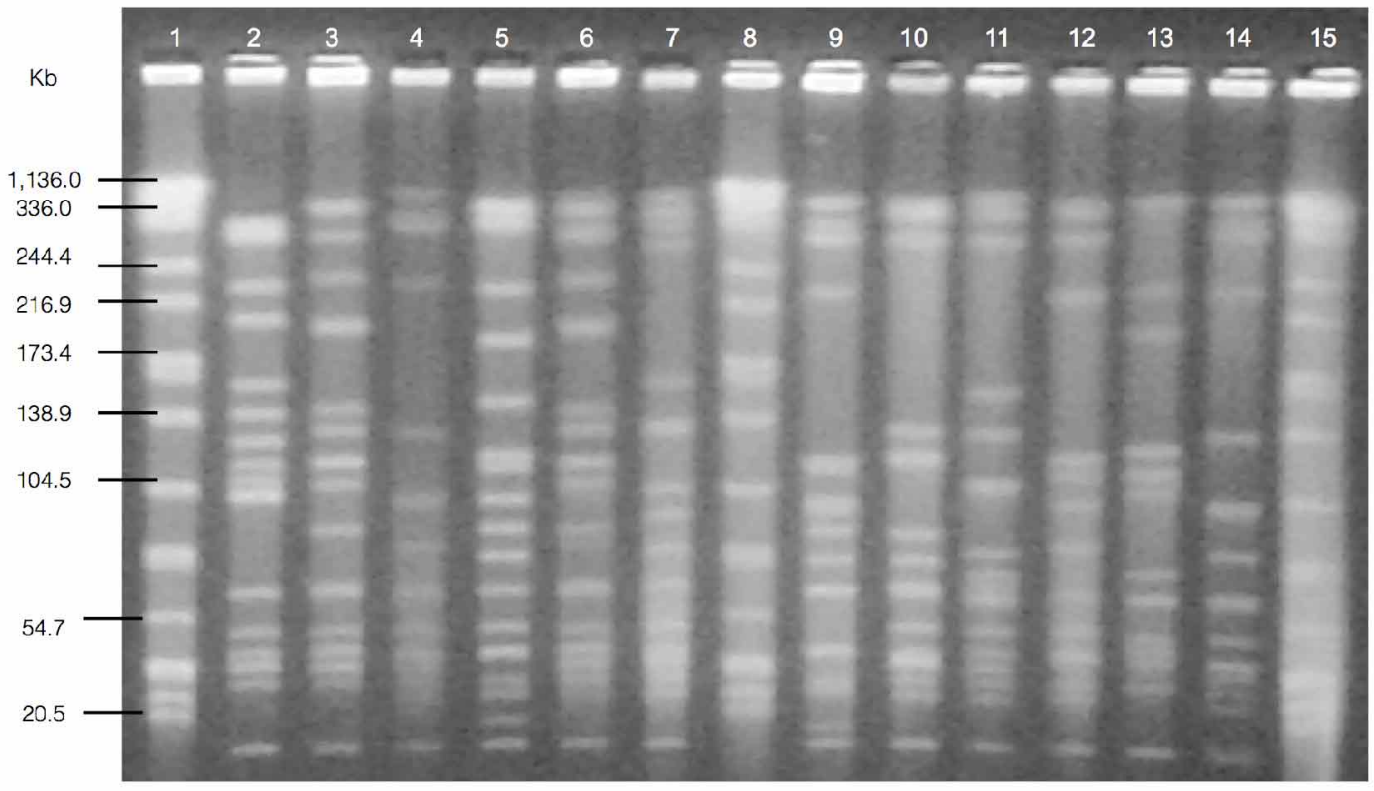

Fig. 1. Representative PFGE fingerprinting of $E$. faecalis strains isolated from root canals diagnosed with persistent endodontic infections. Lanes 1-8-15: Gel size standard strain Salmonella Braenderup. Lanes 2 to 7 and 9 to 14: $E$. faecalis strains. 
SÁNCHEZ-SANHUEZA, G.; VILLEGAS, C.; ULLOA, M. I.; PINEDA, C.; GONZÁLEZ-ROCHA, G.; DOMíNGUEZ, M. \& BELLO-TOLEDO, H. Molecular typing of Enterococcus faecalis from persistent endodontic infections. Int. J. Odontostomat., 12(1):113-119, 2018.

The PFGE analysis by BioNumerics revealed 13 Smal restriction patterns (referred to as pulse types) (A-M). The dendrogram (Fig. 3) was constructed with $35 \mathrm{E}$. faecalis strains that were selected, based on at least one strain per patient and the strains with more than four different bands, per the Tenover criteria.

Table I shows the distribution of the strains and patients for each PFGE fingerprint. Five pulse types $(38.4 \%)$ were present in 2 patients. Therefore, strains from different patients showed a high similarity $(>85$ $\%)$. Six pulse types (46.1\%) presented two closely related subtypes $(A, I, J, K, L, M)$, and one of them (pattern M), with $38.7 \%$ of similarity, separated the strains from patient 8 from the rest.
Table I. Distribution of strains and patients for each PFGE pattern.

\begin{tabular}{cccc}
\hline $\begin{array}{c}\text { PFGE } \\
\text { pattern }\end{array}$ & $\begin{array}{c}\mathrm{n}^{\circ} \text { of } \\
\text { strains }\end{array}$ & $\begin{array}{c}\mathrm{n}^{\circ} \text { of clonal } \\
\text { strains }\end{array}$ & Patient \\
\hline $\mathrm{A}$ & 10 & $5(\mathrm{~A} 1) 5(\mathrm{~A} 2)$ & 9 and 10 \\
$\mathrm{~B}$ & 1 & $1(\mathrm{~B} 1)$ & 10 \\
$\mathrm{C}$ & 1 & $1(\mathrm{C} 1)$ & 9 \\
$\mathrm{D}$ & 5 & $5(\mathrm{D} 1)$ & 16 \\
$\mathrm{E}$ & 12 & $12(\mathrm{E} 1)$ & 5 and 18 \\
$\mathrm{~F}$ & 6 & $6(\mathrm{~F} 1)$ & 15 \\
$\mathrm{G}$ & 5 & $7(\mathrm{G} 1)$ & 7 \\
$\mathrm{H}$ & 6 & $6(\mathrm{H} 1)$ & 12 \\
$\mathrm{I}$ & 7 & $6(\mathrm{I}) 1(\mathrm{I})$ & 4 and 7 \\
$\mathrm{~J}$ & 6 & $5(\mathrm{~J} 1) 1(\mathrm{~J} 2)$ & 10 \\
K & 12 & $5(\mathrm{~K} 1) 7(\mathrm{~K} 2)$ & 2 and 3 \\
L & 6 & $5(\mathrm{~L} 1) 1(\mathrm{~L} 2)$ & 6 and 16 \\
M & 6 & $5(\mathrm{M} 1) 1(\mathrm{M} 2)$ & 8 \\
\hline
\end{tabular}

PFGE E. faecalis Sma I (35 entries) \% Similary Coeficient (85\%)

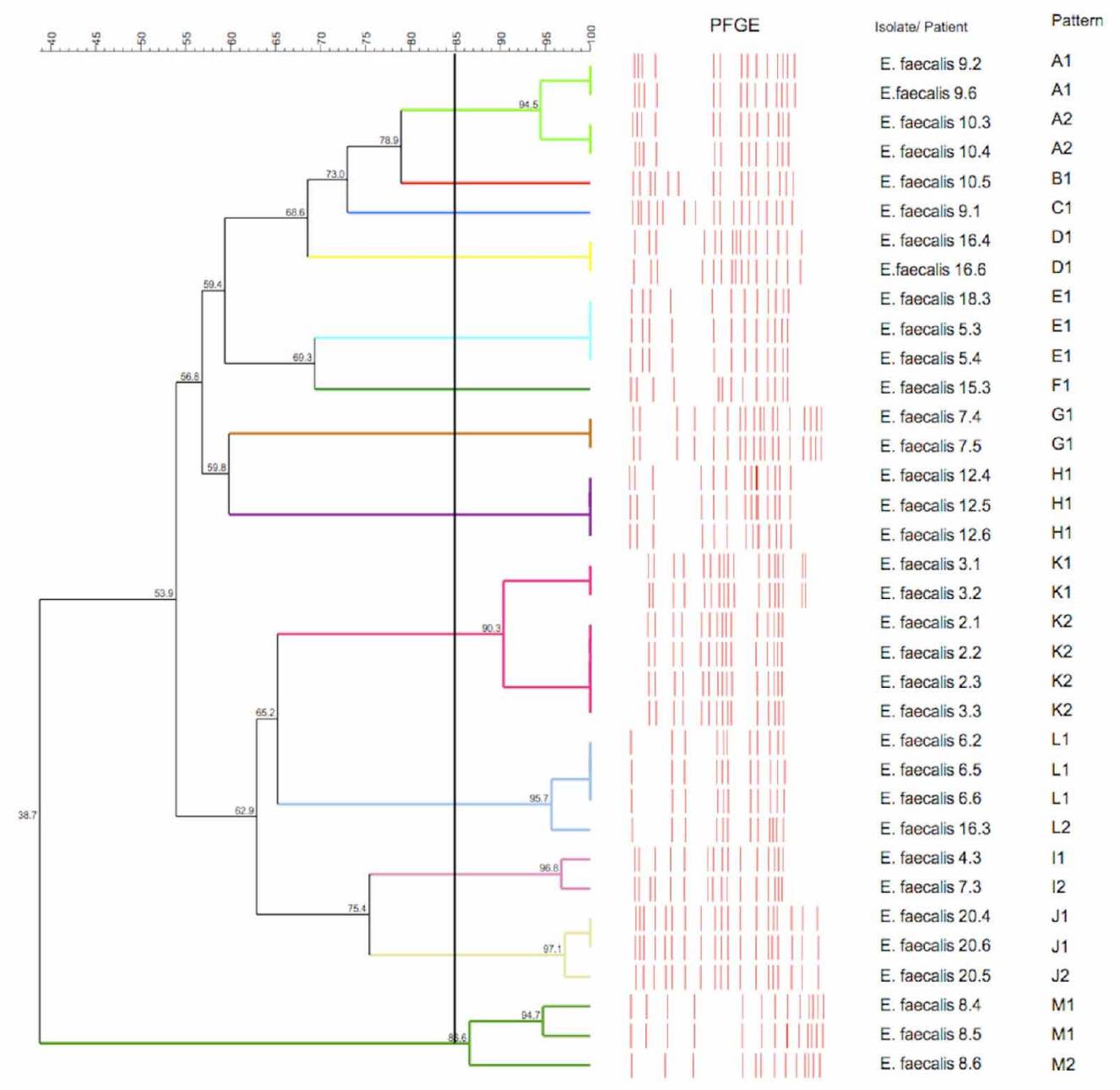

Fig. 3. Dendrogram of $35 E$. faecalis strains isolated from the root canals of patients diagnosed with persistent endodontic infections. In the column for the isolate/patient, the first number refers to the patient, and the second refers to the strain. 


\section{DISCUSSION}

Molecular typing is an important and useful tool for analyzing the epidemiology of microorganisms, and contributes to monitoring infections caused by resistant pathogens from various sources, including the oral cavity (Panesso et al., 2010). Previous studies have evaluated the genetic relatedness of the $E$. faecalis strains from the oral cavity, food and other body places (Anderson et al., 2016). A high genetic heterogeneity was revealed, which was a frequent finding in previous studies comparing strains from different times and places (Sedgley et al., 2004; Vidana et al.; CastilloRojas et al.); these findings are consistent with our results. These studies support the hypothesis that molecular methods, such as PFGE, are highly valid and useful techniques for determining strain clonality. A supragingival isolate from one patient and a nosocomial infection isolate from another patient, obtained on different dates but in the same clinic, were closely related (Anderson et al.). This suggests that there is a possible connection in the circulation of strains in the same clinical environment. Our report describes findings of non-genetically related isolates in a single patient and indistinguishable isolates obtained from different patients on different dates. Moreover, findings of close relatedness and identical virulence genes have been reported for an endodontic strain taken from a German patient, and an isolate coming from a milk plant obtained on different dates (Anderson et al.). Together, these observations corroborate PFGE as a useful tool for complementing data from susceptibility assays and resistance profiles and confirm the importance of typing strains, of understanding the way they circulate in our population, and of their relationship with the presence of resistance determinants.

A high prevalence of $E$. faecalis in the root canals of teeth that are treated for persistent apical periodontitis has been shown by traditional culture and molecular methods and suggests that this species could be key to endodontic treatment failure (Zoletti et al., 2011). Thus, it is important to perform microbial examinations of patients with this pathology to characterize the presence of this bacterial species. Moreover, previous studies have classified diverse isolates by PFGE and characterized virulence factors by REP-PCR to determine interindividual genetic diversity among the isolates obtained from endodontic infections, as observed in our study (Zoletti et al.). From 20 endodontic isolates of $E$. faecalis, 18 restriction profiles grouped in 14 different genotypes were reported, with $50 \%$ of isolates included in 5 genotypes (Zoletti et al.). In present study, which included 83 strains, revealed 19 profiles grouped in 13 different genotypes. Nevertheless, the previous analysis only used the Tenover criteria; $21.5 \%$ of the patients presented strains with at least two different PFGE patterns (Zoletti et al.). A study by Zhu et al. showed that $62 \%$ of the strains from different patients were closely related, and the isolates from the saliva and root canals were different in only one out of the 32 patients studied.

A study by Vidana et al. showed that intrapatient strains from the root canals of Swedish patients were mostly identical or closely related. However, the inter patient strains were not related, differing from the present study's observation of genetic relatedness among strains from different patients. One probable cause of this difference may be that the previous study considered only a visual analysis, using the Tenover criteria, which emphasizes the importance of using Software as Bionumerics, since it offers readings more sensitive than just the use of the visual criterion. The BioNumerics software is a highly sensitive tool that is used and accepted worldwide for epidemiological studies of bacterial strain distributions that are associated with infections. It is important to note that in this study, the patients were a homogenous population, had no parental or social relationship, and only had the geographical location in which they lived in common (surface $37.068,7 \mathrm{~km}^{2}$ ); the only apparent differences involved the quality of the root canal filling (Sánchez-Sanhueza et al.). Nevertheless, it must be emphasized that to complement the information regarding the epidemiological aspects of $E$. faecalis infection in the root canal, it is necessary to isolate $E$. faecalis strains from the oral microbiota of healthy patients to establish whether the strains are genetically related to those of the root canal infection or to transient strains in the oral cavity that can colonize the root canal (Al-Ahmad et al.; Zhu et al.).

Enterococcus faecalis genotype isolates from multiple oral sites using other techniques like REP-PCR and AP-PCR, but with a similar software analysis, using the Dice coefficient, show genetic heterogeneity when compared among different subjects, corroborating the results of present study. REP-PCR shows very similar relatedness with $32.8 \%$ similarity for the less related strains (Delboni et al.). 
The limitations of the present findings are the lack of standardization of typing oral strains, to compare with other reports. Multiple online tools are currently available. For example, those offered by CDC PulseNet work by comparing the results of different studies and by obtaining information of the epidemiological behavior of $E$. faecalis infection worldwide, similarly to the tools used in the medical field for monitoring diverse bacteriological species. Therefore, it would be helpful to standardize the protocols for characterizing $E$. faecalis isolates of oral origins regarding the use of the size marker (lambda DNA ladder (Sedgley et al.), Salmonella Braenderup (Kainer et al.), Staphylococcus aureus (Anderson et al.) and software-based analysis.

Finally, E. faecalis American Type Culture Collection (ATCC) strains are a gold standard in endodontic research, for example to test new antimicrobials (Saatchi et al., 2014; Silva et al., 2014). But ATCC strains are highly susceptible, which may blind the results. Use of clinical $E$. faecalis strains and PFGE typing in microbiological research may improve knowledge in the field of endodontics.

\section{CONCLUSION}

E. faecalis strains with a diverse genetic similarity are circulating among patients treated for Persistent Endodontic Infections, including genetically related $E$. faecalis strains with $>95 \%$ similarity in different patients. This highlights the need for and importance of investigations that focus on the origins of root canal contamination with this bacterial species. PFGE is a recommended tool for typing strains from persistent intra-root canal infections, and further research is necessary to characterize the presence of resistance determinants that circulate in our population, in the different clonal types.

\section{ACKNOWLEDGEMENTS}

This study was funded by Project VRID UDEC $N^{\circ} 214.102 .015-1$. Finally, the authors would like to acknowledge the scholarship provided by CONICYTPCHA/Doctorado Nacional/2013 folio 21130022.
SÁNCHEZ-SANHUEZA, G.; VILLEGAS, C.; ULLOA, M. I.; PINEDA, C.; GONZÁLEZ-ROCHA, G.; DOMÍNGUEZ, M. \& BELLO-TOLEDO, H. Tipificación molecular de Enterococcus faecalis provenientes de infecciones endodónticas persistentes. Int. J. Odontostomat., 12(1):113-119, 2018.

RESUMEN: Las técnicas moleculares proporcionan información valiosa sobre la epidemiología de aislados orales. El propósito de este estudio fue determinar la relación genética de 83 cepas de Enterococcus faecalis aisladas de conductos radiculares tratados. Estas cepas se obtuvieron de pacientes que fueron tratados por infecciones endodónticas persistentes. Los aislados de E. faecalis se tipificaron molecularmente por electroforesis en gel de campo pulsado usando Smal. Se identificaron diez grupos clonales y 13 pulsotipos con un $38,7 \%$ de similitud para las cepas menos relacionadas. Se observó heterogeneidad genética entre las cepas de diferentes pacientes y un alto nivel de homogeneidad genética entre las cepas intrapacientes. Por lo tanto, la toma de huellas dactilares a traves de restricción de ADN genómico de cepas de $E$. faecalis confirmó la policlonalidad de los aislados obtenidos de los conductos radiculares de pacientes diagnosticados con infecciones endodónticas persistentes, en comparación con otros informes. Estos resultados proporcionan datos adicionales para una mejor comprensión de los aspectos epidemiológicos de las infecciones del conducto radicular por E. faecalis.

PALABRAS CLAVE: Enterococcus faecalis, electroforesis de campo pulsado, periodontitis apical no supurativa.

\section{REFERENCES}

Al-Ahmad, A.; Maier, J.; Follo, M.; Spitzmüller, B.; Wittmer, A.; Hellwig, E.; Hübner, J. \& Jonas, D. Food-borne enterococci integrate into oral biofilm: an in vivo study. J. Endod., 36(11):1812-9, 2010.

Anderson, A. C.; Jonas, D.; Huber, I.; Karygianni, L.; Wölber, J.; Hellwig, E.; Arweiler, N.; Vach, K.; Wittmer, A. \& Al-Ahmad, A. Enterococcus faecalis from food, clinical specimens, and oral sites: Prevalence of virulence factors in association with biofilm formation. Front. Microbiol., 6:1534, 2016.

Atila-Pektas, B.; Yurdakul, P.; Gülmez, D. \& Görduysus, Ö. Antimicrobial effects of root canal medicaments against Enterococcus faecalis and Streptococcus mutans. Int. Endod. J., 46(5):413-8, 2013.

Baca, P.; Mendoza-Llamas, M. L.; Arias-Moliz, M. T.; GonzálezRodríguez, M. P. \& Ferrer-Luque, C. M. Residual effectiveness of final irrigation regimens on Enteroccus faecalis-infected root canals. J. Endod., 37(8):1121-3, 2011.

Castillo-Rojas, G.; Mazari-Hiríart, M.; Ponce de León, S.; AmievaFernández, R. I.; Agis-Juárez, R. A.; Huebner, J. \& López-Vidal, Y. Comparison of Enterococcus faecium and Enterococcus faecalis strains isolated from water and clinical samples: antimicrobial susceptibility and genetic relationships. PLoS One, 8(4):e59491, 2013.

Centers for Disease Control and Prevention (CDC). Unified 
PulsedField Gel Electrophoresis (PFGE) protocol for gram positive bacteria. Atlanta, Centers for Disease Control and Prevention (CDC), 2012. Disponible en: https://www.cdc.gov/hai/ pdfs/labsettings/unified_pfge_protocol.pdf

Delboni, M. G.; Gomes, B. P.; Francisco, P. A.; Teixeira, F. B. \& Drake, D. Diversity of Enterococcus faecalis genotypes from multiple oral sites associated with endodontic failure using repetitive sequence-based polymerase chain reaction and arbitrarily primed polymerase chain reaction. J. Endod., 43(3):377-82, 2017.

Hohscheidt, G. L.; Böttcher, D. E.; Fatturi Parolo, C. C.; Montagner, F. \& Grecca, F. S. Response of E. faecalis biofilms to different associations of auxiliary substances during root canal preparation: a confocal laser microscopy analysis. Microsc. Res. Tech., 76(6):658-62, 2013

Javidi, M.; Afkhami, F.; Zarei, M.; Ghazvini, K. \& Rajabi, O. Efficacy of a combined nanoparticulate/calcium hydroxide root canal medication on elimination of Enterococcus faecalis. Aust. Endod. J., 40(2):61-5, 2014.

Kainer, M. A.; Devasia, R. A.; Jones, T. F.; Simmons, B. P.; Melton, K.; Chow, S.; Broyles, J.; Moore, K. L.; Craig, A. S. \& Schaffner, $W$. Response to emerging infection leading to outbreak of linezolid-resistant enterococci. Emerg. Infect. Dis., 13(7):102430, 2007.

Kumar, H. An in vitro evaluation of the antimicrobial efficacy of Curcuma longa, Tachyspermum ammi, chlorhexidine gluconate, and calcium hydroxide on Enterococcus faecalis. J. Conserv. Dent., 16(2):144-7, 2013.

Panesso, D.; Reyes, J.; Rincón, S.; Díaz, L.; Galloway-Peña, J.; Zurita, J.; Carrillo, C.; Merentes, A.; Guzmán, M.; Adachi, J. A.; Murray, B. E. \& Arias, C. A. Molecular epidemiology of vancomycin-resistant Enterococcus faecium: A prospective, multicenter study in South American hospitals. J. Clin. Microbiol., 48(5):1562-9, 2010.

Pladisai, P.; Ampornaramveth, R. S. \& Chivatxaranukul, P. Effectiveness of different disinfection protocols on the reduction of bacteria in Enterococcus faecalis biofilm in teeth with large root canals. J. Endod., 42(3):460-4, 2016.

Ribeiro, R. L.; Machry, L.; Brazil, J. M.; Ramos, T. M.; Avelar, K. E. \& Pereira, M. M. Technical improvement to prevent DNA degradation of Leptospira spp. in pulsed field gel electrophoresis. Lett. Appl. Microbiol., 49(2):289-91, 2009.

Rôças, I. N.; Siqueira, J. F. Jr. \& Santos, K. R. Association of Enterococcus faecalis with different forms of periradicular diseases. J. Endod., 30(5):315-20, 2004.

Saatchi, M.; Shokraneh, A.; Navaei, H.; Maracy, M. R. \& Shojaei, H. Antibacterial effect of calcium hydroxide combined with chlorhexidine on Enterococcus faecalis: a systematic review and meta-analysis. J. Appl. Oral Sci., 22(5):356-65, 2014

Sánchez-Sanhueza, G.; González-Rocha, G.; Dominguez, M. \& Bello-Toledo, H. Enterococcus spp. isolated from root canals with persistent chronic apical periodontitis in a Chilean population. Braz. J. Oral Sci., 14(3):240-5, 2015.

Sedgley, C. M.; Lennan, S. L. \& Clewell, D. B. Prevalence, phenotype and genotype of oral enterococci. Oral Microbiol. Immunol., 19(2):95-101, 2004.

Silva, E. J.; Herrera, D. R.; Rosa, T. P.; Duque, T. M.; Jacinto, R. C.; Gomes, B. P. \& Zaia, A. A. Evaluation of cytotoxicity, antimicrobial activity and physicochemical properties of a calcium aluminatebased endodontic material. J. Appl. Oral Sci., 22(1):61-7, 2014.

Tenover, F. C.; Arbeit, R. D.; Goering, R. V.; Mickelsen, P. A.; Murray, B. E.; Persing, D. H. \& Swaminathan, B. Interpreting chromosomal DNA restriction patterns produced by pulsed-field gel electrophoresis: criteria for bacterial strain typing. J. Clin. Microbiol., 33(9):2233-9, 1995.

Vengerfeldt, V.; Spilka, K.; Saag, M.; Preem, J. K.; Oopkaup, K.; Truu, J. \& Mändar, R. Highly diverse microbiota in dental root canals in cases of apical periodontitis (data of illumina sequencing). J. Endod., 40(11):1778-83, 2014.

Vidana, R.; Sullivan, A.; Billström, H.; Ahlquist, M. \& Lund, B. Enterococcus faecalis infection in root canals - host-derived or exogenous source? Lett. Appl. Microbiol., 52(2):109-15, 2011.

Werner, G.; Coque, T. M.; Franz, C. M.; Grohmann, E.; Hegstad, K.; Jensen, L.; van Schaik, W. \& Weaver, K. Antibiotic resistant enterococci-tales of a drug resistance gene trafficker. Int. J. Med. Microbiol., 303(6-7):360-79, 2013.

Zhu, X.; Wang, Q.; Zhang, C.; Cheung, G. S. \& Shen, Y. Prevalence, phenotype, and genotype of Enterococcus faecalis isolated from saliva and root canals in patients with persistent apical periodontitis. J. Endod., 36(12):1950-5, 2010.

Zoletti, G. O.; Pereira, E. M.; Schuenck, R. P.; Teixeira, L. M.; Siqueira, J. F. Jr. \& dos Santos, K. R. Characterization of virulence factors and clonal diversity of Enterococcus faecalis isolates from treated dental root canals. Res. Microbiol., 162(2):151-8, 2011.

Correspondence author:

Helia Bello-Toledo. MSc, PhD.

Laboratorio de Investigación en Agentes Antibacterianos

Departamento de Microbiología

Facultad de Ciencias Biológicas

Universidad de Concepción

Concepción

CHILE

e-mail: hbello@udec.cl

Received: 09-11-2017

Accepted: 23-12-2017 